REVIEWS

UDC $616.006 .81 ; 577.218$

\title{
Gene targeting in melanoma therapy: exploiting of surface markers and specific promoters
}

\author{
I. V. Alekseenko ${ }^{1,2}$, M. V. Zinovyeva ${ }^{1}$, V. V. Pleshkan ${ }^{1,2}$, \\ E. D. Sverdlov ${ }^{1,2}$ \\ ${ }^{1}$ Shemyakin-Ovchinnikov Institute of Bioorganic Chemistry RAS \\ 16/10, Miklukho-Maklaya, Moscow, Russian Federation, 117997 \\ ${ }^{2}$ Institute of Molecular Genetics RAS \\ 2, Kurchatov Sq., Moscow, Russian Federation, 123182 \\ mzinov@mail.ru
}

\begin{abstract}
One of the problems of gene therapy of melanoma is effective exp ression of therapeutic gene in tumor cells and their metastases but not in normal cells. In this review, we will consider a two-step approach to a highly specific gene therapy. At the first step, therapeutic genes are delivered specifically to tumor cells using cell surface markers of melanoma cells as targets. At the second step, a specific expression of the therapeutic genes in tumor cells is ensured. Surface markers of mela-noma cells were analyzed as potential targets for therapeutic treatment. Criteria for choosing the most promising targets are proposed. The use of specific melanoma promoters allows to further increase the specificity of treatment via transcriptional control of therapeutic gene expression in melanoma cells.
\end{abstract}

Keywords: gene therapy, cell surface markers, melanoma-specific promoters, melanoma.

In recent years the number of patients with malignant melanoma, one of the most aggressive tumors, has been increasing worldwide. One of the main melanoma specificities is early metastasis which results in high mortality rate of patients: survival rate of patients in the course of five years after the beginning of the disease is up to $50 \%$. Due to this fact the therapy for melanoma is related to many hardships, including difficulty of recognizing metastases and high resistance of melanoma cells which conditions poor diagnosis of disease progress $[1,2]$. Up-to-now the main method of therapy for melanoma has been surgical resection of

(C) Institute of Molecular Biology and Genetics, NAS of Ukraine, 2012 affected tissues. Chemo- and radiotherapy prove to be of little effect, as melanoma metastases are often resistant to this treatment [2]. Due to this fact gene therapy suggests new approaches, based on reinforcing the specificity of affecting target malignant cells while decreasing the impact of medicine on healthy cells. One of the main problems of efficient application of therapeutic agents of post-genome generation is the absence of optimal methods of therapeutic gene (transgene) delivery into malignant cells. This problem may be solved using specific surface markers of melanoma cells, bound to ligands, introduced into the composition of a delivering vector. On the other hand, tumor specificity may be added while creating 
conditions for transgene transcription only in specific tissues. In order to meet the second condition, promoters and enhancers, specific for a certain tumor type, are used in constructing therapeutic vectors $[3,4]$. The advantage of using promoters and other regulatory elements, specific only for this tumor, is maximal decrease of side effects. However, promoters, working well in a primary tumor, do not always retain this specificity in its metastases. Therefore, the application of promoters, working in a wide range of tumors, but not in normal cells, seems very promising. These constructions may be universal for therapy of different types of tumors. The combination of target delivery and specific gene expression may contribute considerably to enhancing safety of the therapeutic system.

This review describes markers with increased concentration on the surface of melanoma cells but almost absent on normal non-tumor cells. Special attention is paid to changes in expression profile of melanoma markers in metastases. The possibility of their application for specific recognition of malignant cells while delivering genetic material is considered. There are presented data on surface antigens of melanoma stem cells, promising targets of antitumor therapy. Besides, the structures and features of promoters, specific for melanoma cells as well as promoters, active in a wide range of tumors, are described; the possibility of their application for the purposes of gene therapy for melanoma is discussed.

Surface markers of melanoma. . Surface markers of melanoma cells have been used as subjects of decades-long studies $[5,6]$. The most significant ones are presented below.

Antigens, recognized by cytotoxic T-lymphocytes. Melanoma cells synthesize various antigens, recognized by autologous and specific cytotoxic T-lymphocytes (CTL) when presented in molecular complex with MHC molecules [7]. Some antigens are suitable targets for immune therapy.

Antigens, presented on the surface of melanoma cells, may be divided into four classes [8]. The first class is presented by antigens of melanocyte differentiation. It is comprised of such proteins as tyrosinase (TYR), MLANA, SILV, TRP-1 and TRP-2 [9-11]. Antigens of this class play a key role in the development of melanocytes and have restricted tissue specificity. Transcription of genes, coding proteins of this class, is observed only in melanocytes, in cells of nevus and pigment spots as well as in melanoma cells. High level of such antigens in pigment spots and nevus does not allow distinguishing melanoma cells from non-carcinogenic cells of melanocyte lineage [12]. However, these antigens may serve as highly sensitive diagnostic markers for determination of melanoma cells in blood and metastases [13] and as good targets for therapy of metastases.

The second class is comprised of cancer/testis antigens. They are specific for embryonic cells and are usually absent in tissues of an adult organism, except for testes and placenta $[14,15]$. However, these antigens are considerably present in tumors of different histological origin, including melanomas [16]. Cancer/testis antigens are encoded by three families of genes, expressing them, $-M A G E, B A G E$ and GAGE. Melanoma cells present at least one of specified antigens. Up-to-now the functions of these antigens have not been studied sufficiently. It is supposed that they are involved into the regulation of a cellular cycle and apoptosis [14-16]. Genes CTAG1B (NY-ESO-1) and $L A G E-1$ belong to the second group of cancer/testis antigens [17]. The level of transcription of genes $N Y-E S O-1 / L A G E-1$ in testes and placenta is very high, while it is low in heart, skeletal muscles and pancreas, and gene expression is not detected in other tissues. Increased expression of gene NY-ESO-1 is observed in some types of cancer, in particular, in melanoma cells, and depends on the stage of disease. Increased expression of NY-ESO-1 is associated with poor prognosis for the disease progression [18].

Also, the family of SSX, numbering five representatives, belongs to cancer/testis antigens. Usually they all are expressed in testes; trace amounts are expressed in thyroid gland and detected in many types of cancer [19]. Transcription of gene SSX2 is especially intense at melanoma [20].

Antigens, belonging to two other classes, present on the surface, which are peptide fragments or proteins, the contents of which is considerably increased in different types of tumors (for instance, BIRC5, MUC1/2, AFP and EphA2) as well as tumor-specific antigens, occurring due to point mutations of 
widely-spread genes (p53, Ras, CDK4, MUM1, CTNNB1, CDKN2B/INK4, etc.), are not unique for melanoma cells, and the research thereof is far beyond the framework of this review.

Antigens, predominantly synthesized by melanoma cells. A distinguished group is comprised by surface antigens, the expression of which is specific only for melanoma cells and their metastases. At present there are data about only two of these antigens - MIA (melanoma-inhibiting activity) and MELOE (melanoma-overexpressed antigen). The protein of melanoma-inhibiting activity plays a significant role in invasion and metastasis of melanomas and is deemed as a highly specific and sensitive marker. The expression of MIA gene is found mainly in melanoma, in inconsiderable amounts - in chondrosarcomas, carcinomas of ovaries and kidneys, in cancer of head/neck and is absent in cells of normal skin and nevus $[21,22]$. Recently characterized antigen MELOE is specific only for melanoma cells, it has not been detected in other tissues and tumors. The functions and specificities of this antigen are still unknown [23, 24].

An important factor of melanoma treatment is the delivery of therapeutic genes into metastases. For this reason it is essential to understand in what way the sets of surface markers change in the range of tumors metastases. The analysis of expression profiles of antigens, described above, demonstrated that differentiation antigens SILV, MLANA, TYR in samples of both primary tumors and metastases are at the same level. At the same time cancer/testis antigens MAGE1, MAGE4, NY-ESO-1 are found in primary tumors less often and in smaller amounts than in metastases [25], therefore, they may be targets of therapeutic treatment both in primary tumors and metastases. It was found that the expression of gene MIA increases with the progression of melanoma [26].

Highly specific expression of cancer/testis antigens and antigens of melanocyte differentiation makes them good targets for delivery of gene therapeutic constructions. On the other hand, the unique nature of genetic regulatory apparatus of these genes may be used for the purpose of expression of therapeutic genes in melanomas only.

Melanoma cells receptors are capable of ensuring selective penetration of therapeutic constructions into required cells due to internalization of the receptor. Many reviews are devoted to them [27, 28]. In this review we will dwell upon description of two factors only - melanocortin and tyrosine-kinase (c-Met) receptors, since they are the most promising targets for directed delivery of preparations.

Melanocortin 1 receptor (MC1R). . Five different melanocortin receptors with specific distribution of expression in human tissues were characterized [29]. Only receptor- $\alpha$-melanocyte-stimulating hormone (MC1R) is expressed in melanocytes and melanoma cells. High expression of MC1R is also notable for cell lines from primary and metastatic melanomas, while only minor quantities of this receptor are found in some other tissues and cells $[30,31]$. MC1R receptor is mainly localized inside cells; its amount increases on the surface of cells for metastatic and uveal melanomas [30]. The exposure of MC1R on the surface of cells is induced by some cytokines, like interferon $\gamma$ (IFN- $\gamma$ ), tumor necrosis factor $\alpha$ (TNF- $\alpha$ ), interleukins IL-4 and IL-10 [32]. MC1R receptor has very close affinity to such ligands as adrenocorticotropic and melanocyte-stimulating hormones, capable of specific internalization by cells $[32,33]$. Therefore, this receptor may be considered as a candidate for directed delivery of preparations into melanoma cells.

c-Met receptor (HGFR). . Hepatocyte growth factor receptor c-Met (HGFR) is synthesized in epithelial cells and plays an important role in embryonic development. A natural receptor ligand is hepatocyte growth factor (HGF), the expression of which is also observed in melanoma cells, which results in activation of c-Met receptor, regulating signalling pathways of MAPK and PI3K [34]. High expression of c-Met in primary melanomas stimulates invasive growth of malignant cells and enhances their metastatic potential. Autocrine regulation of $\mathrm{HGF} / \mathrm{c}-\mathrm{Met}$ is important for melanoma development, thus, the disorder in ligand-receptor interaction may cause suppression of melanoma growth [36]. It was shown that antibodies with high affinity to HGF block the binding of the latter to the ligand, inhibit phosphorylation of c-Met, cell proliferation and invasion of tumor cells [37]. While HGF interacts with the receptor, the latter is internalized [38], which enables the application of c-Met as a receptor for the 
introduction of therapeutic agents into the cells if the analogue of HGF ligand is included into the composition of the vector.

Molecules of intracellular interaction.The development of many types of tumors, including melanoma, is accompanied by disorders in expression of genes, coding for cell adhesion proteins [39]. The changes in qualitative and quantitative composition of cell adhesion molecules may serve as prognostic feature of malignization. The cell adhesion molecules (CAM) are presented by a wide class of proteins, divided into families of immunoglobulins, cadherins, selectins, integrins and mucines [40]. The example thereof may be found in proteins of subfamily of CAM immunoglobulins, such as MCAM (CD146, MUC18), L1CAM (CD171), ALCAM (CD166), ICAM1 (CD54), and CEACAM1 (CD66a). Their content is not high in normal melanocytes [39]. During malignization the expression of corresponding genes is constantly increasing, reaching its maximum in metastatic melanoma cells, which promotes the increase in the invasiveness and motility of melanoma cells and the increase in the metastasis level [39, 41, 42]. It is supposed that the majority of cell adhesion molecules condition high metastatic activity of melanoma, and in some cases they are the main effectors of metastasis formation [42]. Considerable density of the mentioned receptors on the surface of melanoma cells makes them a promising target for directed delivery of transgenes. A characteristic feature of the majority of the mentioned cell adhesion molecules is their capability of internalization, which may ensure efficient introduction of the receptor-related vector into the cell [43, 44].

Melanoma-associated antigen with high molecular weight. Significant expression of the gene, coding melanoma-associated antigen with high molecular weight (HMW-MAA), is observed only in melanoma cells and in human melanoma cell lines, but it has not been discovered in normal melanocytes, cells of nevus and pigment spots [45]. The studies of recent years have proven HMW-MAA participation in the activation of some signalling pathways, modulating adhesion, migration, and invasion of melanoma cells $[45,46]$. The capability of HMW-MAA to internalize inside the cell was discovered [47].
Surface markers of melanoma stem cells. . A vast volume of experimental data testifies to the fact that among malignant melanoma cells there is a small population of stem cells, capable of their own reproduction and formation of a tumor [48-51]. This cell population is considered to be the most aggressive. Melanoma stem cells are supposed to be the very providers of resistance to practically all the kinds of chemotherapy $[50,52]$. Several surface markers of melanoma stem cells were revealed and characterized. One of them - membrane marker CD133 - was discovered in less than $1 \%$ of melanoma cells, and these cells had the greatest oncogenic potential [48, 49]. Other markers are P-glycoproteins (ABCB5 and ABCG2), related to MDR family - ATP-dependent transporter proteins, conferring chemoresistance to melanoma cells $[52,53]$. The level of expression for $A B C B 5$ gene is considerably higher in melanoma cells than in nevus [53]. Proteins MHCI and melanoma-specific antigens NY-ESO-1 and MAGE-A are considerably less presented in ABCB5-positive cells [54]. It was recently shown that CD271 marker-positive cells have the greatest potential for melanoma development [50]. These cells have sharp decrease in expression of genes TYR, MART1 and $M A G E C 1 / M A G E C 2$. This fact may serve as explanation of the failures in melanoma therapy using antibodies to protein products of the mentioned genes. However, contrary results were published almost at the same time, demonstrating the greatest oncogenic potential of cells without CD271 [55].

The review [51] suggests heterogeneity of melanoma stem cells and the possibility of existence of cells with different phenotype, carrying different markers in specific conditions. It is supposed that the occurrence of metastases is possible due to migration of carcinogenic stem cells into organs with suitable conditions for their binding. A number of works described the increase in the content of tumor stem cell markers during metastases [50]. There are reasons to believe that therapy for tumors should mainly be directed at the suppression of stem cells.

The use of surface markers of melanoma for directed delivery of therapeutic genes. Up-to-now there are only several known ways of using receptors and surface antigens of melanoma for the therapy of 
this disease. For instance, it was suggested to use the process of cell internalization of toxic preparations, conjugated with specific melanoma markers, for therapy purposes. Promising results were received while using gelonin conjugates with antibodies to HMW-MAA [56]. Melanoma receptors may serve as targets of oncolytic viruses, in particular, Coxsackie virus A21, interacting with ICAM1 receptor [57]. The majority of receptors are present on many normal cells, therefore it is necessary to choose receptors with enhanced expression in melanoma cells proper. The development of methods for identification and destruction of metastases is of great relevance for melanoma treatment. The first priority is attributed to the study of the content of stem cells markers and receptors in melanoma cells and metastases, and the possibility of their application for therapeutic purposes. Besides, it is necessary to search for new marker genes, which could be used for directed impact on metastases.

Promoters that specifically active in melanoma cells. Specificity to a certain type of tissue in the process of creating gene therapeutic constructions is conditioned by the level of expression of transgene, dependent on regulatory systems, in particular, enhancers and promoters, active only in carcinogenic cells. At present promoters of genes of tyrosinase and melanoma-inhibiting activity are the most studied and used for gene therapy of melanoma, sometimes in combination with distal elements of other promoters and/or enhancers. Structures of both human and murine promoters TYR and MIA are studied and described in fine detail [58-60]. Functional comparison proved that human TYR promoter demonstrates less efficiency and specificity of expression in human melanocytes compared to murine promoter. The enhancer has a greater impact on the activity of human $T Y R$ promoter, while the promoter itself is important just for the manifestation of specific activity of a murine gene [58, 61, 62].

A number of works are devoted to description of various combinations of tyrosinase promoter with transcription-controlling cys-regulatory elements heterologous enhancers; their impact on the specificity of transgene expression in melanoma cells was established [58]. The greatest enhancing effect on the activity and specificity of human $T Y R$ promoter is made by binding of several enhancers of murine Tyr. Human enhancing sequences in the same constructions condition only 2-3-fold increase in reporter gene activity [61]. Up-to-now nothing is known about enhancer elements of gene MIA. It was shown that contrary to promoter of TYR gene, the activity of promoter of human MIA gene increases with melanoma progression [60]. The study of the impact of murine Tyr enhancers on the activity of murine Tyr promoter and human MIA revealed that the binding of several enhancers of tyrosinase gene to $M I A$ promoter results in considerable increase in the specific activity of the latter in cells of melanoma lines. Similar to the tyrosinase promoter, murine enhancers have a much higher activity compared to enhancers of human tyrosinase [63]. The inhibition of melanoma cell growth using MIA promoters with four murine Tyr enhancers is slightly less considerable than the effect of a strong constitutive promoter $C M V$ which does not ensure selective expression of the transgene [64].

The data presented demonstrate that the application of different combinations of promoters and enhancers confer high efficiency of expression of transgenes in melanoma cells and may solve the problem of specificity during the therapy of this disease $[63,64]$. The promoter of MIA gene is of special interest, since, contrary to TYR gene, it is expressed only in cells of malignant melanoma, and not in other cells of melanocyte lineage.

It is noteworthy to pay attention to the structure and features of the promoter of melanocortin receptor gene. Similar to $T Y R$ and MIA, melanocyte-specific expression of $M C 1 R$ is activated while binding the transcription factor MITF [65]. 150 b.p. above ATG-codon are sufficient to initiate melanocyte-specific transcription [66]. The minimal promoter of $M C 1 R$ gene may be a promising candidate for the control of transgene expression in melanoma cells. Up-to-now there is no data on the application of this promoter while creating therapeutic constructions.

Promoters specifically active in many types of tumor cells The instances of the best known tumor specific promoters (TSP) are promoters of TERT, Cox -2 and BIRC5 genes. These promoters are notable for increased expression of genes, controlled by them, in many types of tumors, including melanoma, 
compared to the expression in normal tissues [67-69]. For instance, the study of activity of transgenes in cells of melanoma lines, when recombinant adenoviruses were used as vectors, demonstrated that the activity of BIRC5 promoter in normal melanocytes proved to be considerably lower compared to melanoma cells [70]. Using BIRC5 promoter to control the expression of gene of sodium-iodide symporter (NIS), the cells of melanoma line A375 acquire the capability of absorbing radioactive iodine-131 which results in their death, while normal fibroblasts, transfected by the same construction, do not absorb iodine and do not perish [71]. Therefore, BIRC5 promoter shows high tumor-specificity and has good perspectives for its application in therapy for melanoma. However, the majority of TSP have low activity compared to such constitutive strong promoters as SV40 and CMV [71, 72]. There is considerable variability of activity among TSP, depending on the type of carcinogenic cells. In particular, the activity of BIRC5 promoter in different tumor cell lines varies in the range of $0.3-16 \%$ from the activity of CMV promoter, while the efficiency of TERT promoter may differ 20 -fold depending on the cancer cells line $[72,73]$.

Creation and application of chimeric promoters. One of methods of constructing specific promoters with sufficient transcriptional potential, which are short enough to combine with delivery vectors, is the creation of synthetic and/or double (chimeric) promoters. To obtain specific promoter modules de novo, characterized promoters and fragments of regulatory sequences are used. For instance, artificial promoters were constructed on the basis of promoter elements of human TYR gene and $\alpha$-fetoprotein (AFP1), notable for strong and specific expression in the melanoma cell lines [74]. The presence of conservative M-box is remarkable for melanocyte-specific promoters. GRE element and AP1-binding element, specific for the cell cycle, are located in 5'-region of AFPl promoter. Different combinations of the same copy or several copies of $T Y R$ and AFP1 promoter fragments - M-box, AP1- and GRE-elements - were used to obtain several efficient specific promoters and to show their selective activity in the melanoma B16 cell line, but not in the HeLa cells [74]. The activity and specificity of synthetic promoters depend on selected optimal number of regulatory elements. In this case the highest efficiency is demonstrated by the construction of a promoter with three GRE elements, three AP1 elements and two M-boxes with length of about 300 b.p. [74].

The application of hybrid double promoters, one of which is cancer-specific and the other - strong non-specific, or each promoter is tumor-specific, allows enhancing the efficiency of promoters. The example thereof may be found in chimeric promoter $C M V$-TERT, which was created among the first ones [75]. The hybrid construction was obtained on the basis of promoter of human telomerase reverse transcriptase (TERT) and minimal promoter of cytomegalovirus (CMV). This promoter has higher activity than non-modified promoter TERT with preservation of tumor-specificity. Recently the application of other double tumor-specific promoters has also been described [76-78]. The possibility of applying these constructions was shown for the increase in efficiency of transgene expression in the treatment of small-cell lung cancer and breast cancer. The mentioned technology allows reaching a high level of expression of the therapeutic gene in tumor cells, preserving tumor-specificity. Besides, a number of studies demonstrated that the application of double promoters allows obtaining more universal constructions ensuring transgene expression in many types of malignant cells $[76,78]$. At present there are no described systems of double melanoma-specific promoters. However, the creation of constructions on the basis of melanoma-specific promoters, like promoters of MIA, $T Y R$ and MC1R genes, may allow ensuring universal and highly efficient expression of transgenes in melanoma cells.

The application of promoters in gene therapy for melanoma. There are two possible approaches to the application of tumor-specific promoters for gene therapy. The first approach is related to influencing targets - specific molecular components, playing a critical role in carcinogenesis, while the second one is aimed at searching for possibilities of total destruction of tumors. The heterogeneous structure of tumors implies giving preference to the second approach to gene therapy development, usually called suicide therapy $[79,80]$. The method of suicide gene therapy is 
based on the introduction into a malignant cell a gene encoding an enzyme that absent in normal cell and is capable of transforming a non-toxic for normal cells prodrug into the toxin, causing selective death of cancer cells only [80, 81]. The best known and frequently used genes are genes of herpes simplex virus of thymidine kinase $(H S V t k)$ and yeast cytosine deaminase (FCY1). Other killer genes have also been described [82]. The success of applying suicide genes depends on bystander effect to a high degree [40].

Conclusions. Successful application of gene therapy requires selective delivery of therapeutic genes into tumor cells and non-toxicity of these genes for normal cells. Besides, there should be systemic delivery, ensuring the penetration of agents into both primary tumors and metastases, as well as the possibility of quantitative destruction of tumor cells and metastases [83, 84]. The reviewed surface markers of melanoma cells may be applied for the delivery of gene therapy constructions into tumor cells. The delivery of the construction due to binding with surface cell receptor, capable of internalizing by the cell during the interaction with the ligand, seems to be the most efficient [83]. However, as stated above, surface markers are not strictly specific for melanoma cells and are found on the surface of normal cells, although with less density.

Moreover, tumor cells are capable of changing the spectrum of surface determinants to avoid the immune response. Therefore, promoters and enhancers, working specifically in tumors of this tissue, are used to increase the specificity of drug delivery and to decrease side effects on normal cells while constructing vectors $[3,4]$. As for melanoma these are promoters and enhancers of genes, involved into the process of melanin synthesis. The second variant is the application of more universal tumor-specific promoters, capable of working in a wide range of tumors, but not in normal cells. The suitability of therapeutic constructions for melanoma metastases should be taken into account during their development. The combined application of specific promoters and their regulatory elements during the development of gene constructions and surface markers of melanoma cells for the penetration of preparations into the target cells may prove to be a very promising approach to control this fatal disease. The efficiency of applying transgenes may be increased using bystander effect, during which on receiving a therapeutic construction the cancer cells produce a specific product, toxic for neighboring cancer cells, but not toxic for normal cells. According to the known data, in order to destroy all the tumor cells, it is sufficient for the gene to penetrate only $10 \%$ of tumor cells [40].

The methods, described in the review, are at the stage of development, when the most suitable regulatory elements are selected and the constructions are created on their basis. New vectors are matched using both natural viruses and the artificially obtained systems of packing genetic material. It is possible that this development will bring about a simple and efficient system of eliminating melanomas and its metastases.

The work was supported by the Russian President's Grant for Support of the Leading Scientific Schools (5638.2010.4), and Grant of the Presidium of Russian Academy of Sciences (Physical and Chemical Biology) as well as Federal Program, the State Contracts 16.512.12.2002 and 11411.1008700.13.084. И. В. Алексеенко, , М. В. Зиновьева ${ }^{1}$, В. В. Плешкан
длов ${ }^{1,2}$, Е. Д. Свер-

Адресная доставка терапевтических генов при лечении меланомы: роль поверхностных маркеров и специфических промоторов

${ }^{1}$ Учреждение Российской академии наук Институт биоорганической химии

имени академиков М. М. Шемякина и Ю. А. Овчинникова РАН

Ул. Миклухо-Маклая, 16/10, Москва, Российская Федерация, 117997

${ }^{2}$ Учреждение Российской академии наук Институт молекулярной генетики РАН

Пл. Академика И. В. Курчатова, 2, Москва, Российская Федерация, 123182

Резюме

Одной из проблем генной терапии злокачественной меланомы является иеленаправленная экспрессия терапевтического гена в опухолевых клетках и их метастазах при минимизации ее в нормальных клетках. В обзоре рассмотрен двухэтапный подход к высокоспецифичной терапии. На первом этапе осуще- ствляется адресная доставка терапевтических генов в опухолевые клетки с использованием в качестве мишени поверхностных маркеров меланомных клеток, на втором - обеспечивается специфичность экспрессии генов в опухолевых клетках. Проведен анализ поверхностных маркеров меланомных клеток с точки зрения применения их как мишеней для терапевтического воздействия. 
Предложены критерии выбора наиболее перспективных мишеней. Использование промоторов, активных только в меланомных клетках, позволяет еще больше увеличить специфичность воздействия за счет контроля транскрипции терапевтических генов в таких клетках

Ключевые слова: генная терапия, поверхностные маркеры, промоторы, меланома.

\section{I. В. Алексеєнко, М. В. Зінов'єва, В. В. Плешкан, С. Д. Свердлов}

Адресна доставка терапевтичних генів

при лікуванні меланоми:

роль поверхневих маркерів і специфічних промоторів

\section{Резюме}

Однією з проблем генної терапї̈ злоякісної меланоми є ичілеспрямована експресія терапевтичного гена в пухлинних клітинах $і$ їх ніх метастазах за мінімізачї ї̈ у нормальних клітинах. В огляді розглянуто двоетапний підхід до високоспецифічної терапії. На першому етапі здійснюється адресна доставка терапевтичних генів у пухлинні клітини з використанням як мімені поверхневих маркерів меланомних клітин, на другому - забезпечується спеичифічність експресії генів у пухлинних клітинах. Проведено аналіз поверхневих маркерів меланомних клітин з точки зору застосування їх як мішеней для терапевтичної дії. Запропоновано критерії вибору найперспективніших мішеней. Використання промоторів, активних лише в меланомних клітинах, дозволяє збільшити специифічність дї за рахунок контролю транскрипції терапевтичних генів у таких клітинах.

Ключові слова: генна терапія, поверхневі маркери, промотори, меланома

\section{REFERENCES}

1. Atallah E., Flaherty L. Treatment of metastatic malignant melanoma // Curr. Treat. Options Oncol.-2005.-6, N 3.-P. 185-193.

2. Ganesan P., Bakhshi S. Systemic therapy for melanoma // Natl Med. J. India.-2010.-23, N 1.-P. 21-27.

3. Robson T., Hirst D. G. Transcriptional targeting in cancer gene therapy // J. Biomed. Biotechnol.-2003.-2003, N 2.-P. 110-137.

4. Saukkonen K., Hemminki A. Tissue-specific promoters for cancer gene therapy // Expert Opin. Biol. Ther.-2004.-4, N 5.P. 683-696.

5. Haass N. K., Smalley K. S. Melanoma biomarkers: current status and utility in diagnosis, prognosis, and response to therapy // Mol. Diagn. Ther.-2009.-13, N 5.-P. 283-296.

6. Agarwala S. S. Novel immunotherapies as potential therapeutic partners for traditional or targeted agents: cytotoxic T-lymphocyte antigen-4 blockade in advanced melanoma // Melanoma Res.-2010.-20, N 1.-P. 1-10.

7. Boon T., van der Bruggen P. Human tumor antigens recognized by T lymphocytes // J. Exp. Med.-1996.-183, N 3.-P. 725-729.

8. Vujanovic L., Butterfield L. H. Melanoma cancer vaccines and anti-tumor T cell responses // J. Cell. Biochem.-2007.-102, N 2.P. 301-310.
9. Brichard V. G., Herman J., Van Pel A., Wildmann C., Gaugler B., Wolfel T., Boon T., Lethe B. A tyrosinase nonapeptide presented by HLA-B44 is recognized on a human melanoma by autologous cytolytic T lymphocytes // Eur. J. Immunol.-1996.-26, N 1.-P. 224-230.

10. Coulie P. G., Brichard V., Van Pel A., Wolfel T., Schneider J., Traversari C., Mattei S., De Plaen E., Lurquin C., Szikora J. P., Renauld J. C., Boon T. A new gene coding for a differentiation antigen recognized by autologous cytolytic $\mathrm{T}$ lymphocytes on HLA-A2 melanomas // J. Exp. Med.-1994.-180, N 1.-P. 35-42.

11. Bakker A. B., Schreurs M. W., de Boer A. J., Kawakami Y., Rosenberg S. A., Adema G. J., Figdor C. G. Melanocyte lineagespecific antigen $g p 100$ is recognized by melanoma-derived tumor-infiltrating lymphocytes // J. Exp. Med.-1994.-179, N 3.P. 1005-1009.

12. Ohsie S. J., Sarantopoulos G. P., Cochran A. J., Binder S. W. Immunohistochemical characteristics of melanoma // J. Cutan. Pathol.-2008.-35, N 5.-P. 433-444.

13. Arenberger P., Arenbergerova M., Gkalpakiotis S., Lippert J., Stribrna J., Kremen J. Multimarker real-time reverse transcription-PCR for quantitative detection of melanoma-associated antigens: a novel possible staging method // J. Eur. Acad. Dermatol. Venereol.-2008.-22, N 1.-P. 56-64.

14. Simpson A. J., Caballero O. L., Jungbluth A., Chen Y. T., Old L. $J$. Cancer/testis antigens, gametogenesis and cancer// Nat. Rev. Cancer.-2005.-5, N 8.-P. 615-625.

15. Feng Y., Gao J., Yang $M$. When MAGE meets RING: insights into biological functions of MAGE proteins // Protein Cell.-2, N 1.-P. 7-12.

16. Boel P., Wildmann C., Sensi M. L., Brasseur R., Renauld J. C., Coulie P., Boon T., van der Bruggen P. BAGE: a new gene encoding an antigen recognized on human melanomas by cytolytic $\mathrm{T}$ lymphocytes // Immunity.-1995.-2, N 2.-P. 167-175.

17. Rimoldi D., Rubio-Godoy V., Dutoit V., Lienard D., Salvi S., Guillaume P., Speiser D., Stockert E., Spagnoli G., Servis C., Cerottini J. C., Lejeune F., Romero P., Valmori D. Efficient simultaneous presentation of NY-ESO-1/LAGE-1 primary and nonprimary open reading frame-derived CTL epitopes in melanoma // J. Immunol.-2000.-165, N 12.-P. 7253-7261.

18. Velazquez E. F., Jungbluth A. A., Yancovitz M., Gnjatic S., Adams S., O'Neill D., Zavilevich K., Albukh T., Christos P., Mazumdar M., Pavlick A., Polsky D., Shapiro R., Berman R., Spira J., Busam K., Osman I., Bhardwaj N. Expression of the cancer/ testis antigen NY-ESO-1 in primary and metastatic malignant melanoma (MM)-correlation with prognostic factors // Cancer Immun.-2007.-7.-P. 11-17.

19. Gure A. O., Tureci O., Sahin U., Tsang S., Scanlan M. J., Jager E., Knuth A., Pfreundschuh M., Old L. J., Chen Y. T. SSX: a multigene family with several members transcribed in normal testis and human cancer // Int. J. Cancer.-1997.-72, N 6.P. 965-971. 
20. Caballero O. L., Chen Y. T. Cancer/testis (CT) antigens: potential targets for immunotherapy // Cancer Sci.-2009.-100, N 11.P. 2014-2021.

21. Bosserhoff A. K., Echtenacher B., Hein R., Buettner R. Functional role of melanoma inhibitory activity in regulating invasion and metastasis of malignant melanoma cells in vivo // Melanoma Res.-2001.-11, N 4.-P. 417-421.

22. Perez R. P., Zhang P., Bosserhoff A. K., Buettner R., Abu-Hadid $M$. Expression of melanoma inhibitory activity in melanoma and nonmelanoma tissue specimens // Hum. Pathol.-2000.-31, N 11.P. 1381-1388.

23. Godet Y., Moreau-Aubry A., Guilloux Y., Vignard V., Khammari A., Dreno B., Jotereau F., Labarriere N. MELOE-1 is a new antigen overexpressed in melanomas and involved in adoptive $\mathrm{T}$ cell transfer efficiency // J. Exp. Med.-2008.-205, N 11.P. 2673-2682.

24. Rogel A., Vignard V., Bobinet M., Labarriere N., Lang F. A long peptide from MELOE-1 contains multiple HLA class II T cell epitopes in addition to the HLA-A*0201 epitope: an attractive candidate for melanoma vaccination // Cancer Immunol. Immunother.-2011.-60, N 3.-P. 327-337.

25. Barrow C., Browning J., MacGregor D., Davis I. D., Sturrock S., Jungbluth A. A., Cebon J. Tumor antigen expression in melanoma varies according to antigen and stage // Clin. Cancer Res.2006.-12, N 3, Pt 1.-P. 764-771.

26. Kluger H. M., Hoyt K., Bacchiocchi A., Mayer T., Kirsch J., Kluger Y., Sznol M., Ariyan S., Molinaro A., Halaban R. Plasma markers for identifying patients with metastatic melanoma // Clin. Cancer Res.-17, N 8.-P. 2417-2425.

27. Kwong L., Chin L., Wagner S. N. Growth factors and oncogenes as targets in melanoma: lost in translation? // Adv. Dermatol.2007.-23.-P. 99-129.

28. O'Connell M. P., Weeraratna A. T. Hear the Wnt Ror: how melanoma cells adjust to changes in Wnt // Pigment Cell Melanoma Res.-2009.-22, N 6.-P. 724-739.

29. Gantz I., Konda Y., Tashiro T., Shimoto Y., Miwa H., Munzert G., Watson S. J., DelValle J., Yamada T. Molecular cloning of a novel melanocortin receptor // J. Biol. Chem.-1993.-268, N 11.P. 8246-8250.

30. Salazar-Onfray F., Lopez M., Lundqvist A., Aguirre A., Escobar A., Serrano A., Korenblit C., Petersson M., Chhajlani V., Larsson $O$., Kiessling $R$. Tissue distribution and differential expression of melanocortin 1 receptor, a malignant melanoma marker // Br. J. Cancer.-2002.-87, N 4.-P. 414-422.

31. Roberts D. W., Newton R. A., Beaumont K. A., Helen L. J., Sturm R. A. Quantitative analysis of $M C 1 R$ gene expression in human skin cell cultures // Pigment Cell Res.-2006.-19, N 1.P. 76-89.

32. Lopez M. N., Pereda C., Ramirez M., Mendoza-Naranjo A., Serrano A., Ferreira A., Poblete R., Kalergis A. M., Kiessling R., Salazar-Onfray $F$. Melanocortin 1 receptor is expressed by uveal malignant melanoma and can be considered a new target for di- agnosis and immunotherapy // Invest. Ophthalmol. Vis. Sci.2007.-48, N 3.-P. 1219-1227.

33. Star R. A., Rajora N., Huang J., Stock R. C., Catania A., Lipton $J$. $M$. Evidence of autocrine modulation of macrophage nitric oxide synthase by alpha-melanocyte-stimulating hormone // Proc. Natl Acad. Sci. USA.-1995.-92, N 17.-P. 8016-8020.

34. Li G., Schaider H., Satyamoorthy K., Hanakawa Y., Hashimoto K., Herlyn M. Downregulation of E-cadherin and Desmoglein 1 by autocrine hepatocyte growth factor during melanoma development // Oncogene.-2001.-20, N 56.-P. 8125-8135.

35. Christensen J. G., Burrows J., Salgia R. c-Met as a target for human cancer and characterization of inhibitors for therapeutic intervention // Cancer Lett.-2005.-225, N 1.-P. 1-26.

36. Marquette A., Bagot M., Bensussan A., Dumaz N. Recent discoveries in the genetics of melanoma and their therapeutic implications // Arch. Immunol. Ther. Exp. (Warsz).-2007.-55, N 6.P. 363-372.

37. Burgess T., Coxon A., Meyer S., Sun J., Rex K., Tsuruda T., Chen Q., Ho S. Y., Li L., Kaufman S., McDorman K., Cattley R. C., Sun J., Elliott G., Zhang K., Feng X., Jia X. C., Green L., Radinsky $R$., Kendall $R$. Fully human monoclonal antibodies to hepatocyte growth factor with therapeutic potential against hepatocyte growth factor/c-Met-dependent human tumors // Cancer Res.-2006.-66, N 3.-P. 1721-1729.

38. Naka D., Shimomura T., Yoshiyama Y., Sato M., Sato M., Ishii T., Hara H. Internalization and degradation of hepatocyte growth factor in hepatocytes with down-regulation of the receptor/c-Met // FEBS Lett.-1993.-329, N 1-2.-P. 147-152.

39. Johnson J. P. Cell adhesion molecules in the development and progression of malignant melanoma // Cancer Metastasis Rev.1999.-18, N 3.-P. 345-357.

40. Mesnil M., Crespin S., Avanzo J. L., Zaidan-Dagli M. L. Defective gap junctional intercellular communication in the carcinogenic process // Biochim. Biophys. Acta.-2005.-1719, N 1-2.P. $125-145$.

41. van Kempen L. C., van den Oord J. J., van Muijen G. N., Weidle U. H., Bloemers H. P., Swart G. W. Activated leukocyte cell adhesion molecule/CD166, a marker of tumor progression in primary malignant melanoma of the skin // Am. J. Pathol.-2000.156, N 3.-P. 769-774.

42. Thies A., Berlin A., Brunner G., Schulze H. J., Moll I., Pfuller U., Wagener C., Schachner M., Altevogt P., Schumacher U. Glycoconjugate profiling of primary melanoma and its sentinel node and distant metastases: implications for diagnosis and pathophysiology of metastases // Cancer Lett.-2007.-248, N 1.P. 68-80.

43. Piazza T., Cha E., Bongarzone I., Canevari S., Bolognesi A., Polito L., Bargellesi A., Sassi F., Ferrini S., Fabbi M. Internalization and recycling of ALCAM/CD166 detected by a fully human single-chain recombinant antibody // J. Cell Sci.-2005.118, Pt 7.-P. 1515-1525.

44. Pearl R. A., Pacifico M. D., Richman P. I., Wilson G. D., Grover $R$. Stratification of patients by melanoma cell adhesion molecule 
(MCAM) expression on the basis of risk: implications for sentinel lymph node biopsy // J. Plast. Reconstr. Aesthet. Surg.2008.-61, N 3.-P. 265-271.

45. Campoli M. R., Chang C. C., Kageshita T., Wang X., McCarthy $J$. B., Ferrone $S$. Human high molecular weight-melanoma-associated antigen (HMW-MAA): a melanoma cell surface chondroitin sulfate proteoglycan (MSCP) with biological and clinical significance // Crit. Rev. Immunol.-2004.-24, N 4.-P. 267-296.

46. Goto Y., Arigami T., Murali R., Scolyer R. A., Tanemura A., Takata M., Turner R. R., Nguyen L., Nguyen T., Morton D. L., Ferone $S$., Hoon D. S. High molecular weight-melanoma-associated antigen as a biomarker of desmoplastic melanoma // Pigment Cell Melanoma Res.-2010.-23, N 1.-P. 137-140.

47. Chan M. C., Murphy R. M. Kinetics of cellular trafficking and cytotoxicity of 9.2.27-gelonin immunotoxins targeted against the high-molecular-weight melanoma-associated antigen // Cancer Immunol. Immunother.-1999.-47, N 6.-P. 321-329.

48. Fang D., Nguyen T. K., Leishear K., Finko R., Kulp A. N., Hotz S., Van Belle P. A., Xu X., Elder D. E., Herlyn M. A tumorigenic subpopulation with stem cell properties in melanomas // Cancer Res.-2005.-65, N 20.-P. 9328-9337.

49. Schatton T., Murphy G. F., Frank N. Y., Yamaura K., WaagaGasser A. M., Gasser M., Zhan Q., Jordan S., Duncan L. M., Weishaupt C., Fuhlbrigge R. C., Kupper T. S., Sayegh M. H., Frank $M$. H. Identification of cells initiating human melanomas // Nature.-2008.-451, N 7176.-P. 345-349.

50. Boiko A. D., Razorenova O. V., van de Rijn M., Swetter S. M., Johnson D. L., Ly D. P., Butler P. D., Yang G. P., Joshua B., Kaplan M. J., Longaker M. T., Weissman I. L. Human melanomainitiating cells express neural crest nerve growth factor receptor CD271 // Nature.-2010.-466, N 7302.-P. 133-137.

51. Hoek K. S., Goding C. R. Cancer stem cells versus phenotypeswitching in melanoma // Pigment Cell Melanoma Res.2010.-23, N 6.-P. 746-759

52. Frank N. Y., Margaryan A., Huang Y., Schatton T., WaagaGasser A. M., Gasser M., Sayegh M. H., Sadee W., Frank M. H. ABCB5-mediated doxorubicin transport and chemoresistance in human malignant melanoma // Cancer Res.-2005.-65, N 10.P. 4320-4333.

53. Monzani E., Facchetti F., Galmozzi E., Corsini E., Benetti A., Cavazzin C., Gritti A., Piccinini A., Porro D., Santinami M., Invernici G., Parati E., Alessandri G., La Porta C. A. Melanoma contains CD133 and ABCG2 positive cells with enhanced tumourigenic potential // Eur. J. Cancer.-2007.-43, N 5.-P. 935-946.

54. Schatton T., Schutte U., Frank N. Y., Zhan Q., Hoerning A., Robles S. C., Zhou J., Hodi F. S., Spagnoli G. C., Murphy G. F., Frank $M$. H. Modulation of T-cell activation by malignant melanoma initiating cells // Cancer Res.-2010.-70, N 2.-P. 697-708.

55. Held M. A., Curley D. P., Dankort D., McMahon M., Muthusamy $V$., Bosenberg M. W. Characterization of melanoma cells capable of propagating tumors from a single cell // Cancer Res.2010.-70, N 1.-P. 388-397.
56. Selbo P. K., Rosenblum M. G., Cheung L. H., Zhang W., Berg K. Multi-modality therapeutics with potent anti-tumor effects: photochemical internalization enhances delivery of the fusion toxin scFvMEL/rGel // PLoS One.-2009.-4, N 8.-P. e6691.

57. Au G. G., Lincz L. F., Enno A., Shafren D. R. Oncolytic Coxsackievirus A21 as a novel therapy for multiple myeloma // Br. J. Haematol.-2007.-137, N 2.-P. 133-141.

58. Shibata K., Muraosa Y., Tomita Y., Tagami H., Shibahara S Identification of a cis-acting element that enhances the pigment cell-specific expression of the human tyrosinase gene // J. Biol. Chem.-1992.-267, N 29.-P. 20584-20588.

59. Golob M., Buettner R., Bosserhoff A. K. Characterization of a transcription factor binding site, specifically activating MIA transcription in melanoma // J. Invest. Dermatol.-2000.-115, N 1.-P. 42-47.

60. Bosserhoff A. K., Lederer M., Kaufmann M., Hein R., Stolz W., Apfel R., Bogdahn U., Buettner R. MIA, a novel serum marker for progression of malignant melanoma // Anticancer Res.-1999.19, N 4A.-P. 2691-2693.

61. Peter I., Graf C., Dummer R., Schaffner W., Greber U. F., Hemmi $S$. A novel attenuated replication-competent adenovirus for melanoma therapy // Gene Ther.-2003.-10, N 7.-P. 530-539.

62. Lillehammer T., Tveito S., Engesaeter B. O., Fodstad O., Maelandsmo G. M., Engebraaten $O$. Melanoma-specific expression in first-generation adenoviral vectors in vitro and in vivo - use of the human tyrosinase promoter with human enhancers // Cancer Gene Ther.-2005.-12, N 11.-P. 864-872.

63. Rothfels H., Paschen A., Schadendorf D. Evaluation of combined gene regulatory elements for transcriptional targeting of suicide gene expression to malignant melanoma // Exp. Dermatol.2003.-12, N 6.-P. 799-810.

64. Schoensiegel F., Paschen A., Sieger S., Eskerski H., Mier W., Rothfels H., Kleinschmidt J., Schadendorf D., Haberkorn U. MIA (melanoma inhibitory activity) promoter mediated tissuespecific suicide gene therapy of malignant melanoma // Cancer Gene Ther.-2004.-11, N 6.-P. 408-418.

65. Rouzaud F., Hearing $V$. J. Regulatory elements of the melanocortin 1 receptor // Peptides.-2005.-26, N 10.-P. 1858-1870.

66. Miccadei S., Pascucci B., Picardo M., Natali P. G., Civitareale $D$. Identification of the minimal melanocyte-specific promoter in the melanocortin receptor 1 gene // J. Exp. Clin. Cancer Res.2008.-27.-P. 71-79.

67. Denkert C., Kobel M., Berger S., Siegert A., Leclere A., Trefzer $U$., Hauptmann $S$. Expression of cyclooxygenase 2 in human malignant melanoma // Cancer Res.-2001.-61, N 1.-P. $303-$ 308.

68. Robledo M. M., Bartolome R. A., Longo N., Rodriguez-Frade J. M., Mellado M., Longo I., van Muijen G. N., Sanchez-Mateos P., Teixido J. Expression of functional chemokine receptors CXCR3 and CXCR4 on human melanoma cells // J. Biol. Chem.-2001.276, N 48.-P. 45098-45105. 
69. Slater M., Scolyer R. A., Gidley-Baird A., Thompson J. F., Barden J. A. Increased expression of apoptotic markers in melanoma // Melanoma Res.-2003.-13, N 2.-P. 137-145.

70. Lu B., Makhija S. K., Nettelbeck D. M., Rivera A. A., Wang M., Komarova S., Zhou F., Yamamoto M., Haisma H. J., Alvarez R. D., Curiel D. T., Zhu Z. B. Evaluation of tumor-specific promoter activities in melanoma // Gene Ther.-2005.-12, N 4.-P. 330-338.

71. Huang R., Zhao Z., Ma X., Li S., Gong R., Kuang A. Targeting of tumor radioiodine therapy by expression of the sodium iodide symporter under control of the survivin promoter // Cancer Gene Ther.-2011.-18, N 2.-P. 144-152.

72. Gu J., Fang B. Telomerase promoter-driven cancer gene therapy // Cancer Biol. Ther.-2003.-2, N 4, Suppl. 1.-P. S64-70.

73. Konopka K., Spain C., Yen A., Overlid N., Gebremedhin S., Duzgunes $N$. Correlation between the levels of survivin and survivin promoter-driven gene expression in cancer and non-cancer cells // Cell. Mol. Biol. Lett.-2009.-14, N 1.-P. 70-89.

74. Martinelli R., De Simone V. Short and highly efficient synthetic promoters for melanoma-specific gene expression // FEBS Lett.2005.-579, N 1.-P. 153-156.

75. Davis J. J., Wang L., Dong F., Zhang L., Guo W., Teraishi F., Xu $K$., Ji L., Fang B. Oncolysis and suppression of tumor growth by a GFP-expressing oncolytic adenovirus controlled by an hTERT and CMV hybrid promoter// Cancer Gene Ther.-2006.-13, N 7.P. 720-723.

76. Poulsen T. T., Pedersen N., Juel H., Poulsen H. S. A chimeric fusion of the hASH1 and EZH2 promoters mediates high and specific reporter and suicide gene expression and cytotoxicity in small cell lung cancer cells // Cancer Gene Ther.-2008.-15, N 9.P. 563-575.

77. Farokhimanesh S., Rahbarizadeh F., Rasaee M. J., Kamali A., Mashkani B. Hybrid promoters directed $t$ Bid gene expression to breast cancer cells by transcriptional targeting // Biotechnol. Prog.-2010.-26, N 2.-P. 505-511.

78. Amit D., Hochberg A. Development of targeted therapy for bladder cancer mediated by a double promoter plasmid expressing diphtheria toxin under the control of H19 and IGF2-P4 regulatory sequences // J. Transl. Med.-2010.-8.-P. 134-151.

79. Denny $W$. A. Prodrugs for gene-directed enzyme-prodrug therapy (suicide gene therapy) // J. Biomed. Biotechnol.-2003.2003, N 1.-P. 48-70.

80. Sverdlov E. D. Not gene therapy, but genetic surgery - the right strategy to attack cancer // Mol. Gen. Microbiol. Virol.-2009.24, N 3.-P. 93-113.

81. Ezzeddine Z. D., Martuza R. L., Platika D., Short M. P., Malick A., Choi B., Breakefield X. O. Selective killing of glioma cells in culture and in vivo by retrovirus transfer of the herpes simplex virus thymidine kinase gene // New Biol.-1991.-3, N 6.-P. 608 614.

82. Stritzker J., Pilgrim S., Szalay A. A., Goebel W. Prodrug converting enzyme gene delivery by $L$. monocytogenes // BMC Cancer.-2008.-8, N 1.-P 94-103.

83. Xu L., Huang C. C., Huang W., Tang W. H., Rait A., Yin Y. Z., Cruz I., Xiang L. M., Pirollo K. F., Chang E. H. Systemic tumor-targeted gene delivery by anti-transferrin receptor scFv-immunoliposomes // Mol. Cancer Ther.-2002.-1, N 5.-P. 337-346.

84. Liu Y., Tao J., Li Y., Yang J., Yu Y., Wang M., Xu X., Huang C., Huang $W$., Dong J., Li L., Liu J., Shen G., Tu Y. Targeting hypoxia-inducible factor-1alpha with Tf-PEI-shRNA complex via transferrin receptor-mediated endocytosis inhibits melanoma growth // Mol. Ther.-2009.-17, N 2.-P. 269-277.

Received 10.10.11 